This PDF is a selection from a published volume from the National Bureau of Economic Research

Volume Title: U.S. Engineering in a Global Economy

Volume Author/Editor: Richard B. Freeman and Hal Salzman, editors

Volume Publisher: University of Chicago Press

Volume ISBNs: 978-0-226-46833-4 (cloth); 978-0-226-46847-1 (e-ISBN)

Volume URL: http://www.nber.org/books/free12-1

Conference Date: September 26-27, 2011

Publication Date: April 2018

Chapter Title: The Influence of Licensing Engineers on Their Labor Market

Chapter Author(s): Yoon Sun Hur, Morris M. Kleiner, Yingchun Wang

Chapter URL: http://www.nber.org/chapters/c12688

Chapter pages in book: (p. $217-241)$ 


\title{
The Influence of Licensing Engineers on Their Labor Market
}

\author{
Yoon Sun Hur, Morris M. Kleiner, and Yingchun Wang
}

Shortages and surpluses of engineers are a recurrent labor market problem in the United States, which have attracted considerable public and professional attention.

-R. B. Freeman (1976)

\subsection{Introduction}

Analysts of the labor market for engineers have often documented the phenomenon of recurring booms and busts (Hansen 1961; Folk 1970; Freeman 1976). One potential public policy solution has been to regulate the market for engineers, especially ones that require licenses to practice within the occupation, and thereby reduce market volatility for engineers through the use of occupational planners to determine the appropriate supply of engineers. With this type of regulation and planning, perhaps these wide swings, which result in uncertainty for both employers and those considering entering the occupation, could be reduced. Besides the stated public policy rationale that labor market regulation improves public health and safety, it also may serve to reduce fluctuations in the market for engineers. Licensing may create a "web of rules" that results in a more orderly functioning of the labor market for the occupation that reduces uncertainty and variance in quality and sets the rules for entry and exit within the occupation, which provides a source of social insurance (Dunlop 1958). Further, engineers and

Yoon Sun Hur is an associate research fellow at the Korea Institute for International Economic Policy (KIEP). Morris M. Kleiner is professor of public affairs at the Humphrey School at the University of Minnesota and a research associate of the National Bureau of Economic Research. Yingchun Wang is assistant professor of management at the University of Houston, Downtown.

We thank the editors for suggestions on earlier versions of the chapter. We appreciate the work of Rebecca Furdek, William Stancil, and Timothy Teicher, and are grateful for their excellent assistance with the statutory and other legal data used in this study. We also thank Richard Freeman, Hwikwon Ham, Aaron Schwartz, and participants at the NBER/Sloan Engineering Project Workshop for their helpful comments and advice. For acknowledgments, sources of research support, and disclosure of the authors' material financial relationships, if any, please see http://www.nber.org/chapters/c12688.ack. 
the functioning of their labor markets are viewed as important contributors to innovation and economic growth. An analysis that sheds light on the functioning of these labor markets may contribute to an understanding of how institutional factors influence engineering's contribution to technological change. However, if the influence of licensing for engineers is similar to markets for other regulated occupations, it may then restrict the supply of labor, causing an increase in wages and a reduction in the utilization of engineers in production (Kleiner and Kudrle 2000; Kleiner and Todd 2009; Kleiner 2013).

The general policy issue of occupational licensing is an important and growing one in the U.S. labor market, since it is among the fastest-growing labor market institutions in the U.S. economy. For example, in the 1950s about 4.5 percent of the workforce was covered by licensing laws by state government (Kleiner 2006). By 2008 approximately 29 percent of the U.S. workforce had attained licensing by any level of government, and by the 1990s more than 800 occupations were licensed by at least one state (Brinegar and Schmitt 1992; Princeton Data Improvement Initiative [PDII] 2008; Kleiner and Krueger 2010, 2013). This figure compares with about 12.6 percent of the members of the workforce who said they were union members, another institution that looks after its members, in the Current Population Survey (CPS) for the same year; that value was down to 11.3 percent by the end of 2012 (Hirsch and Macpherson 2011; U.S. Department of Labor 2013). Although we do not have detailed information on the trends for the licensing of engineers, their level of unionization has declined, which is consistent with national trends. Figure 7.1 shows the decline in unionization for civil, electrical, and industrial engineers from 1983 to 2010. The steepest dip was for electrical engineers, where unionization declined from about 12.2 percent in 1983 to 4.8 percent in 2010 . The smallest decline was for industrial engineers, whose rates of unionization declined from 9.2 percent to 8.3 percent over the same time period. We will focus our analysis on these engineering specialties for this chapter, since they represent a continuum of more to less regulated specialties in engineering.

Since occupational regulation has many forms, describing its various types is worthwhile. The occupational regulation of engineers in the United States generally takes three forms. The least restrictive form is registration, in which individuals file their names, addresses, and qualifications with a government agency before practicing their occupation. The registration process may include posting a bond or filing a fee. In contrast, certification permits any person to perform the relevant tasks, but the government-or sometimes a private, nonprofit agency-administers an examination or other method to determine qualifications and certifies those who have achieved the level of skill and knowledge for certification. For example, travel agents and car mechanics are generally certified but not licensed. The toughest form of regulation is licensure; this form of regulation is often referred to 


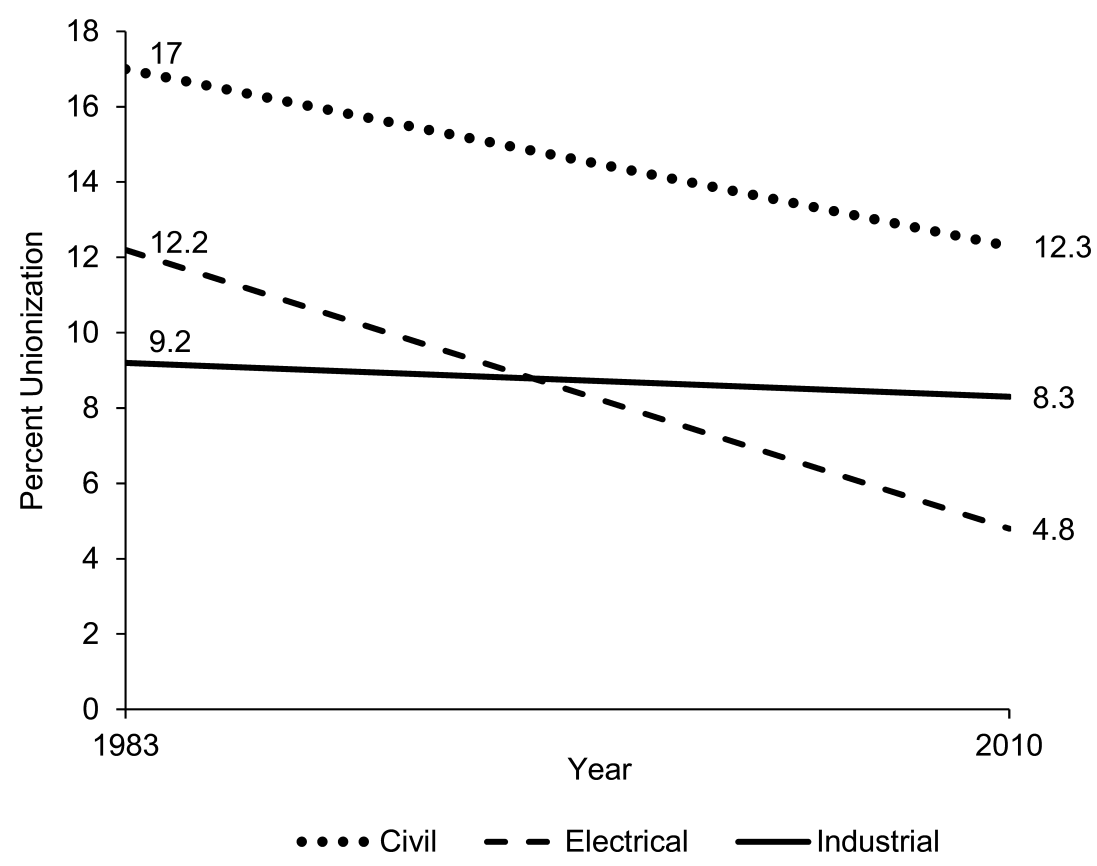

Fig. 7.1 Decline in unionization for civil, electrical, and industrial engineers, 1983-2010

Source: Current Population Survey, various years calculated by the authors.

as "the right to practice." Under licensure laws, working in an occupation for compensation without first meeting government standards is illegal. Our analysis provides a first look at the role of occupational licensing, rather than the other two forms of governmental regulation in the labor market for engineers in the United States.

We examine the role for occupational licensing in the labor market for engineers from 2001 through 2012. Initially, we present the evolution and anatomy of occupational licensing for engineers. Next, we present a theory of licensing and show how this form of regulation leads to wages dropping to the competitive wage as the licensing authority increases the supply of practitioners. In the following section, we show the data for the analysis and present the growth of regulation for the three types of engineers in our data set. Next, we present our empirical analysis for three large specialties in engineering - civil, electrical, and industrial - when variations in occupational licensing characteristics such as examinations and pass rates are included. In the final section, we summarize our results.

The theoretical model shows that government-granted licenses to protect the public can also lead to rents for the members of the occupation. As more individuals are allowed into the occupation by the planner, wages fall. To the 
extent that regulation reduces innovation and that unregulated members of the occupation can do higher wage tasks, regulation may diminish wages. The estimates in our models are small for the labor market effects of licensing, and they depend on the requirements and the engineering specialty examined. Also, some evidence indicates that some licensing requirements influence the number of hours worked by engineering specialty. The studies of the influence of licensing statutes on labor market outcomes perhaps need better data on individuals who have a license rather than just state licensing coverage, since coverage biases downward the influence of this type of regulation (Gittleman and Kleiner 2016). In this study we focus on licensing coverage rather than attainment, since determining attainment is possible only when individual data explicitly ask whether an individual was licensed.

\subsection{The Evolution and Anatomy of Licensing for Engineers}

Similar to other occupations that eventually became licensed, such as dentists and nurses, the government regulation of engineers began in the early 1900s (Council of State Governments 1952). The first state to pass a licensure law was Wyoming in 1907. At the time, Wyoming engineers were concerned with water speculators who lacked the qualifications or experience of trained engineers but nonetheless used the term "engineer." The law was passed so that "all the surveying and engineering pertaining to irrigation works should be properly done" (Russell and Stouffer 2003, 1). The American Society of Civil Engineers (ASCE) supported this piece of legislation, but otherwise resisted the notion of state-controlled licensing. After 1910, many civil engineering associations supported the concept of state licensing in order to control specific aspects of the practice that would be regulated. The ASCE promulgated a model law for licensure in 1910. This shift in policy also helped the occupation of civil engineering to be consistent with regulations that were being developed in other professions such as medicine and law, which had already accepted licensure (Haber 1991; Pfatteicher 1996). The effort to license the occupation was largely driven by engineering professional associations, but employers largely opposed rigorous regulations. Nevertheless, they were willing to agree to license the occupation if they also had the flexibly to employ unregulated practitioners to do most tasks.

Around 1920, the National Council of State Boards of Engineering Examiners was formed to work for licensure in every state, help enforce regulations, and ensure appropriate levels of experience and education for professional practice. This organization evolved into the National Council of Examiners for Engineering and Surveying (NCEES). As more states adopted regulations for professional practice, these engineering associations also became involved in advocating for the standardization of engineering curricula in professional schools and universities. It took nearly forty-five years for all fifty states to require licensure for the practice of civil engineer- 
Percentage of engineers licensed by specialty, 1995 and 2012

\begin{tabular}{lcc}
\hline Engineering discipline & Percentage licensed 1995 & Percentage licensed 2012 \\
\hline Civil & 44 & 31 \\
Electrical & 9 & 9 \\
Industrial & 8 & 9 \\
\hline
\end{tabular}

Sources: For 1995, Paul Taylor, NCEES Licensure Bulletin, December 1995; for 2012, the Survey of Income and Program Participation, 2013.

ing, although these licenses were required only for certain types of tasks that engineers perform.

In contrast, chemical, electrical, mechanical, and petroleum engineering were recognized as title holders and were covered by licensing following World War II. In the 1960s, industrial engineering was recognized as a title branch and was also regulated. Table 7.1 shows the percentage of engineers licensed by specialty in the United States, according to the National Council of Examiners for Engineering and Surveying (NCEES) in 1995 and from the Survey of Income and Program Participation (SIPP) for 2012. Civil engineering was by far the most regulated branch of engineering, with more than 44 percent of those practicing being licensed in 1995. This value declined to 31 percent in the SIPP in 2012. As the estimates in table 7.1 show, about 9 percent of the electrical engineers were licensed in the mid-1990s and in 2012, and about 8 to 9 percent of industrial engineers were licensed in the mid-1990s and in 2012. This suggests a large variance in the amount of regulation in the occupation of engineering. Moreover, the vast majority of engineers are covered by licensing statutes, but do not attain a license.

To measure the level of difficulty that each of the states sets for becoming a professional engineer, we develop an index of restrictiveness of engineer regulation. Not only has the level of licensing increased, but the intensity of the process of becoming licensed has become more difficult. Based on conversations with key officials at the NCEES, as well as with focus groups comprising engineers, architects, and interior designers, we have identified the following central items as important in becoming licensed: a general age/education requirement, experience requirements, a written exam, a practical performance exam, a specific engineering specialty exam, reciprocity requirements from other states, and a continuing education requirement. ${ }^{1}$ These elements are the basis of an index of the rigor of the licensing process, in addition to the type of licensing. Using this index, we can trace the evolution of the intensity of the licensing index in the period 1995-2012. Table 7.3 summarizes the index of licensing regulations for engineers. The results show a slight upward movement in the mean values

1. We met and discussed with officials at the Minnesota Board of Architecture, Engineering, Land Surveying Landscape Architecture, Geoscience and Interior Design (AELSLAGID) regarding key criteria for licensing in that state and with several licensed engineers in Minnesota, Arizona, and California. 
and a narrower spread in the variance of the licensing provisions across states. Occupational licensing is growing among states, and its provisions to enter and maintain good standing as a licensed professional engineer are becoming more stringent.

The nation's umbrella engineering-licensing body embraced a so-called Model Rule that would extend by thirty the number of extra credit hours engineers with bachelor of science degrees must attain to gain a professional license, but no state licensing board has made it a reality. However, the deadline for the professional association is in 2020. The goals of the licensing groups are to increase the status of engineers. For example, Blaine Leonard, former ASCE president and supporter of the increased requirements for becoming a licensed engineer, stated the following: "If we want to meet challenges and be prepared to protect the public, engineers need more depth of knowledge. You can't get it in programs under pressure." Proponents would like to see engineering attain the same professional status as medicine and accounting. The National Academy of Engineering and the National Society of Professional Engineers support the idea (Rubin and Tuchman 2012).

\subsection{Basic Theory}

To provide a theoretical context for our empirical work, we first review a model of the influence of licensing on the supply of labor. In the following section, we focus on the demand for labor and how government can be an important factor within a licensing model. The analysis of wage determination under licensing in engineering builds on work by Perloff (1980) on the influence of licensing laws on wage changes in the construction industry. The basic model posits that market forces are largely responsible for wage determination and that demand for work is highly cyclical. This approach also would apply to the engineering labor market. Perloff presents two cases. In the first, there are no costs to shifting across industries so that labor supply is completely elastic at the opportunity wage. In this case, the increase in the demand for work would have little effect on wages, since workers would flow between varying industries. The introduction of a licensing law renders the supply of labor inelastic. In this case, labor cannot flow between the sectors so that variations in demand would be reflected in the wage. In his empirical work, Perloff shows that for electricians, more so than for either laborers or plumbers, state regulations make the supply curve highly inelastic. Consequently, the ability of a state to limit entry or impose major costs on entry through licensing would enhance the occupation's ability to raise wages or allow them to fall during declines in the demand for labor, and retain levels of employment. We would expect that a similar approach would apply to the market for engineers, with more inelastic supply curves for civil engineers relative to electrical and industrial engineers. 
Unlike the work that has been developed on the supply side, relatively little analysis has been done on how degrees of restriction of labor supply with occupational licensing influence wages and the amount of work, and how such restrictions of supply can make the labor market deviate from a competitive market. Our model focuses on the supply restriction of labor, and we develop a general model that we will apply to the regulation of engineers. We develop a model as follows:

Let $Q \equiv \sum_{i=1}^{n} q_{i}$, where $q_{i}$ is each engineer's work output, $n$ is the number of engineers in the market, and $Q$ is the total quantity of supply. Each engineer's monetary utility function is $U_{i}=Q_{i} P(Q)-D_{i}\left(q_{i}\right)$, where $D$ denotes the engineer's disutility and $P$ is the price of work output (i.e., wage). The first-order condition for utility maximization is $P(Q)-D_{i}^{\prime}\left(q_{i}\right)+q_{i} P^{\prime}(Q)=0$.

From the above equation, we have $\left[P(Q)-D_{i}^{\prime}\left(q_{i}\right)\right] / P=\left(q_{i} / Q\right) /-\left[P / P^{\prime}(Q) Q\right]$ $=(\alpha / \varepsilon)(1)$, where $\alpha \equiv q_{i} / Q$ is engineer $i$ 's market share, and $\varepsilon \equiv-\left[P^{\prime}(Q) Q\right]$ is the elasticity of demand. Thus, the gap between price and marginal disutility is proportional to the engineer's market share and inversely proportional to the elasticity of demand. Price exceeds the engineer's marginal disutility as long as $\alpha$ is nonzero. The larger the difference, the more prices deviate from the socially efficient price.

For instance, for the symmetric case in which every engineer has the same output, with linear demand, $P(Q)=1-a Q$ for all $i$, and the convex disutility function being $D=b q+c q^{2}$. We assume that $a, b$, and $c$ are greater than zero, so that the demand is inversely related to price and the disutility is a convex function. The first-order condition of the engineer's utility maximization becomes $1-a Q-b-2 c q_{i}=0$. The equilibrium is symmetric for this model: $Q=n q$, where $q$ is the output per engineer. Hence, we obtain $q=(1-b) /$ $(a n+2 c+a)(2)$. The market price is $p=b+[(1-b)(2 c+a) /(a n+2 c+a)]$ (3), and each engineer's utility is $U=\left[(1-b)^{2}(a+c)\right] /\left[(a n+2 c+a)^{2}\right](4)$.

The number of engineers, $n$, is an exogenous variable in the model. It is decided by the restrictions such as an examination requirement and the pass rate for the licensing exam. The stricter the licensing examination, the smaller the $n$. Equations (2) to (4) show that when the licensing requirement is stricter, the incumbent engineers' wage, output per person (measured as work hours in the empirical section), and utility will all increase.

From the above results and equation (1), we have $\left[\left(P\left(Q-D_{i}^{\prime}\left(q_{i}\right)\right] / P=\right.\right.$ $\alpha / \varepsilon=a(1-b) /(a b n+2 c+a)$. So another implication of the model is that the fewer the number of engineers, the further the wage will deviate from the socially efficient wage $\left(p=D^{\prime}\left(q_{i}\right)\right)$. Conversely, when the number of engineers becomes very large $(n \rightarrow \infty)$, the wage tends to become the competitive wage. This would be the case when other unlicensed engineers can largely serve as substitutes for regulated engineers. Therefore, the prediction of the model is that the greater the supply restrictions, the larger the deviation from the competitive model. 
Table 7.2

Key elements in development of the licensing index for engineers

\begin{tabular}{|c|c|}
\hline Major components & Definition \\
\hline $\begin{array}{l}\text { Education } \\
\text { requirement }\end{array}$ & $\begin{array}{l}\text { Three if minimum level of education required to be licensed is } \\
\text { bachelor's degree, two if it is associate's degree, one if board } \\
\text { decides, otherwise zero }\end{array}$ \\
\hline $\begin{array}{l}\text { Experience } \\
\text { requirement }\end{array}$ & $\begin{array}{l}\text { Three if minimum level of education required to be licensed is } \\
\text { eight years, two if it is four years, one if it is two years, zero if no } \\
\text { requirement }\end{array}$ \\
\hline $\begin{array}{l}\text { Professional exam } \\
\text { requirement }\end{array}$ & One if professional exam is required to be licensed, otherwise zero \\
\hline $\begin{array}{l}\text { Fundamental exam } \\
\text { requirement }\end{array}$ & One if fundamental engineering exam is required, otherwise zero \\
\hline $\begin{array}{l}\text { Interim exam } \\
\text { requirement }\end{array}$ & One if exam required for interim permit, otherwise zero \\
\hline $\begin{array}{l}\text { Continuing education } \\
\text { requirement }\end{array}$ & $\begin{array}{l}\text { One if state has any requirement for continuing education, } \\
\text { otherwise zero }\end{array}$ \\
\hline $\begin{array}{l}\text { Specific exam } \\
\text { requirement }\end{array}$ & $\begin{array}{l}\text { One if specific additional exam is required for engineering } \\
\text { discipline, otherwise zero }\end{array}$ \\
\hline
\end{tabular}

Source: Developed by the authors.

\subsection{Data, Model, and Estimation}

Using the above model as our guide, we now present the details of the information on the regulations facing engineers and the labor market conditions of the three broadly representative types of engineers: civil, electrical, and industrial. We chose these types of engineers because they reflect a continuum of regulation ranging from civil engineers who are the most regulated, electrical engineers less so, and industrial engineers the least regulated by state statutes. Table 7.2 displays the key elements (and their operational definition) of the licensing provisions in the statutes and administrative provisions that we plan to examine for each of the states in our sample for engineers.

Table 7.3 shows the yearly growth in the occupational licensing statutes index over the period 1995-2012. The results indicate that the occupation experienced growth in regulations governing entry and training requirements. The level of the index or the number of items included in the statelevel measure grew from 6.94 to 7.25 , or by about 4 percent over this time period. This reflects the intensity of the growth of requirements to enter and maintain the status as a licensed engineer. Further, the standard deviation declined by almost 23 percent, suggesting greater standardization of the requirements for licensing across states and over time.

Table 7.4 shows the relative ranking of the states that have the highest and lowest values in the index. We also developed values that were established through an expert systems focus group approach to test the sensitivity of the results to alternative methods of evaluation of standards. In this approach, an engineering student and a law student were given the data and 
Table 7.3 Growth of occupational licensing intensity over time

\begin{tabular}{lccccc}
\hline Year & No. of state & Mean & Std. dev. & Min. & Max. \\
\hline 1995 & 51 & 6.94 & 2.04 & 0.00 & 9.00 \\
1996 & 51 & 6.86 & 2.03 & 0.00 & 9.00 \\
1997 & 51 & 6.89 & 1.86 & 0.00 & 9.00 \\
1998 & 51 & 7.08 & 1.71 & 0.00 & 9.00 \\
1999 & 51 & 7.08 & 1.71 & 0.00 & 9.00 \\
2000 & 51 & 7.06 & 1.70 & 0.00 & 9.00 \\
2001 & 51 & 7.06 & 1.70 & 0.00 & 9.00 \\
2002 & 51 & 7.06 & 1.70 & 0.00 & 9.00 \\
2003 & 51 & 7.06 & 1.70 & 0.00 & 9.00 \\
2004 & 51 & 7.08 & 1.72 & 0.00 & 9.00 \\
2005 & 51 & 7.08 & 1.72 & 0.00 & 9.00 \\
2006 & 51 & 7.08 & 1.72 & 0.00 & 9.00 \\
2007 & 51 & 7.08 & 1.72 & 1.00 & 9.00 \\
2008 & 51 & 7.08 & 1.72 & 1.00 & 9.00 \\
2009 & 51 & 7.08 & 1.72 & 1.00 & 9.00 \\
2010 & 51 & 7.25 & 1.59 & 1.00 & 9.00 \\
2011 & 51 & 7.25 & 1.59 & 1.00 & 9.00 \\
2012 & 51 & 7.25 & 1.58 & 1.00 & 9.00 \\
\hline
\end{tabular}

Note: Index is the summated rating value of the key provisions for licensing engineers as noted in table 7.2 , tabulated by the authors.

Table 7.4

Regulation rankings of top and bottom states by restrictiveness of licensing, 2009

\begin{tabular}{lclc}
\hline Top states & Index & Bottom states & Index \\
\hline Pennsylvania & 9 & Virginia & 1 \\
Georgia & 9 & Minnesota & 3 \\
Texas & 9 & South Dakota & 4 \\
Illinois & 9 & District of Columbia & 5 \\
Arizona & 9 & Delaware & 5 \\
Colorado & 9 & Connecticut & 5 \\
\hline
\end{tabular}

asked to rank the states based on issues that were personally important to them as professionals in their respective fields. There was a high degree of consistency for the empirical and qualitative approaches. For many states, we were able to obtain the pass rates for the licensing examination for engineers. ${ }^{2}$ Figure 7.2 shows the states and time trend in years for which we were able to obtain from the licensing boards of each of the states that posted their overall engineering pass rates. ${ }^{3}$ The plots in the figure show

2. The links to the boards were available at http://ncees.org/licensing-boards. We went to the data from each state to obtain pass rates.

3. Tables 7A.1, 7A.2, and 7A.3 in the appendix show the influence of the variations in the pass rates and the influence of the statutory provisions of test requirements on both wages and hours of work for a limited number of states in which the data were available. 

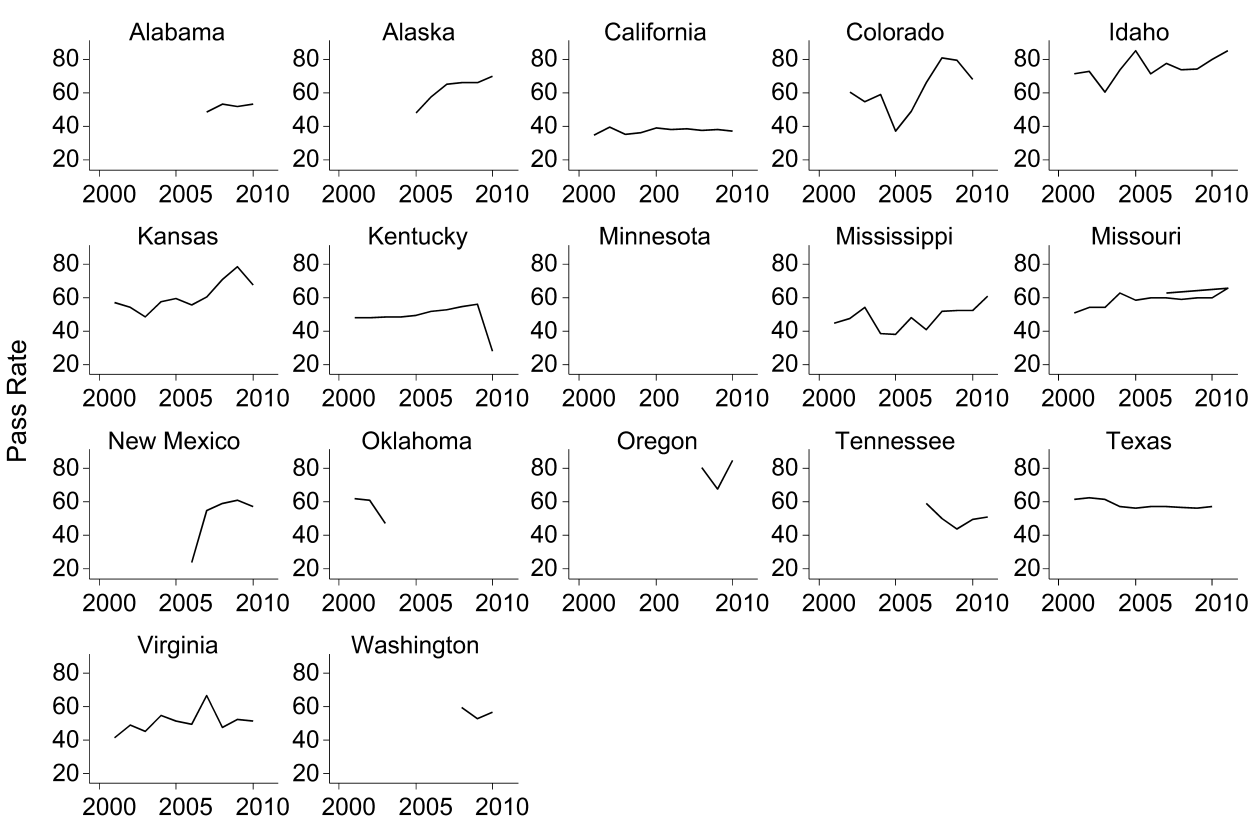

200020052010200020052010

Year

Fig. 7.2 Engineering exam pass rates by state

Sources: The pass-rate data for those states that post this information were obtained from http://ncees.org/licensing-boards/. In addition, we contacted the state boards to obtain pass rates for engineers for others not posted.

that California has the lowest steady-state pass rate for the engineering exam, averaging about 40 percent per year. In contrast, the pass rate for the licensing of engineers in Idaho is well above 80 percent. Unfortunately, no systematic national estimates could be developed because of the state data limitations over time and across states.

\subsubsection{Economic Data}

As a key part of our examination of the influence of regulation on the labor market for engineers, we use data from the American Community Survey (ACS) from 2001 through 2012. Table 7.5 presents the basic information that we used for our analysis. These variables include the standard variables from the ACS to include Mincer-type human capital variables such as gender, age, experience, education, and race. Unfortunately, no data on union status are available in the ACS. The means and standard deviations for the basic variables in the ACS are included in table 7.5 by type of engineer. They show that there are small differences in human capital characteristics such as age, experience, or education across engineering specialties. However, the percentage of civil engineers who work for the govern- 
Key variables for engineers in the ACS, 2001-2012

\begin{tabular}{|c|c|c|c|c|c|c|}
\hline & \multicolumn{2}{|c|}{ Civil engineers } & \multicolumn{2}{|c|}{$\begin{array}{l}\text { Electrical } \\
\text { engineers }\end{array}$} & \multicolumn{2}{|c|}{$\begin{array}{l}\text { Industrial } \\
\text { engineers }\end{array}$} \\
\hline & Mean & S.D. & Mean & S.D. & Mean & S.D. \\
\hline Age & 43.05 & 11.27 & 43.48 & 10.65 & 43.76 & 10.83 \\
\hline Schooling (in year) & 16.00 & 1.67 & 16.21 & 1.66 & 15.70 & 1.66 \\
\hline Gender (male: 1 ; female: 0 ) & 0.74 & 0.44 & 0.91 & 0.28 & 0.81 & 0.39 \\
\hline $\begin{array}{l}\text { Married (married: } 1 ; \text { not } \\
\text { married: } 0 \text { ) }\end{array}$ & 0.73 & 0.45 & 0.76 & 0.43 & 0.74 & 0.44 \\
\hline Experience (in year) & 21.05 & 11.40 & 21.28 & 10.89 & 22.06 & 11.11 \\
\hline Experience squared & 572.88 & 495.33 & 571.25 & 473.94 & 610.37 & 492.57 \\
\hline White (white: 1 ; others: 0 ) & 0.84 & 0.36 & 0.79 & 0.41 & 0.87 & 0.34 \\
\hline Black (black: 1; others: 0 ) & 0.05 & 0.22 & 0.04 & 0.20 & 0.04 & 0.19 \\
\hline $\begin{array}{l}\text { Citizen (U.S. citizen: } 1 \text {; } \\
\text { others: } 0 \text { ) }\end{array}$ & 0.95 & 0.21 & 0.91 & 0.29 & 0.94 & 0.23 \\
\hline $\begin{array}{l}\text { Work for for-profit (yes: } 1 \text {; } \\
\text { no: } 0 \text { ) }\end{array}$ & 0.70 & 0.64 & 0.88 & 0.32 & 0.93 & 0.26 \\
\hline $\begin{array}{l}\text { Work for not-for-profit } \\
\quad \text { (yes: } 1 \text {; no: } 0 \text { ) }\end{array}$ & 0.04 & 0.49 & 0.02 & 0.14 & 0.01 & 0.11 \\
\hline $\begin{array}{l}\text { Work for government (yes: } \\
\quad 1 \text {; no: } 0 \text { ) }\end{array}$ & 0.24 & 0.62 & 0.09 & 0.28 & 0.05 & 0.22 \\
\hline $\begin{array}{l}\text { Self-employment (yes: } 1 \text {; } \\
\text { no: } 0 \text { ) }\end{array}$ & 0.05 & 0.49 & 0.01 & 0.12 & 0.01 & 0.08 \\
\hline $\begin{array}{l}\text { Hourly earnings (in } 2009 \\
\text { dollars) }\end{array}$ & 34.61 & 21.20 & 37.47 & 18.41 & 30.35 & 14.72 \\
\hline
\end{tabular}

Source: American Community Survey.

ment (about 24 percent) and are self-employed (about 5 percent) is much higher than in the other two types of engineering subgroups. The hourly earnings of electrical engineers (about $\$ 37$ per hour) are the highest of the three categories. Generally, the licensing requirements for civil engineers have been in force the longest and are the most detailed across states. The estimates for hours worked are also derived from the ACS. Since there are more observations over time for civil engineers, we have information for all states and years for this category. For electrical and industrial engineers, however, some state and year observations are missing in the ACS, so states such as Wyoming, Hawaii, Montana, and South Dakota are missing observations for a couple of years in our sample.

\subsubsection{Wage Determination}

Our empirical strategy is to first examine the three categories of engineers - civil, electrical, and industrial - that may vary greatly by the type of regulation that influences their ability to find employment. We estimate the model using all engineers in the categories together and then estimate wage equations for each group separately. In figure 7.3 we show kernel density 
Kernel density estimate

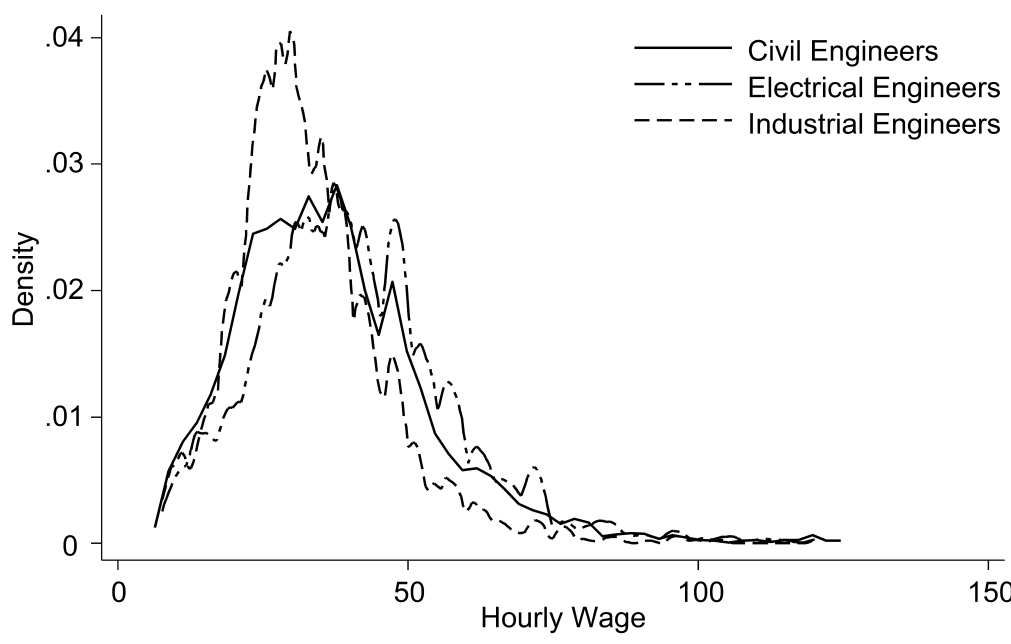

kernel $=$ epanechnikov, bandwidth $=1.1666$

Fig. 7.3 Empirical distribution of hourly rates for three types of engineers, 2009 Source: Current Population Survey, various years.

Note: Sample includes those engineers who make above the minimum wage and excludes those with hourly wages greater than the top 1 percent.

plots for the three types of engineers in our study. The results show that electrical engineers have the highest mean value for wages and the widest distribution of earnings among the three types of engineers we study, but industrial engineers have the lowest mean value.

Our basic model uses an earnings function and compares the three types of engineers (the least regulated one - industrial engineers - is the excluded category). Our basic model is of the following form:

$$
\ln \left(\text { Earnings }_{i s t}\right)=\alpha+\beta R_{i s t}+\gamma X_{i s t}+T_{i s t}+\delta_{i s t}+\theta_{t}+\varepsilon_{i s t},
$$

where Earnings ist $_{i s}$ the hourly earnings of engineer $i$ at state $s$ in year $t ; T_{i s t}$ is the type of engineer (civil, electrical, or industrial) for person $i$ 's state $s$ in year $t ; R_{i s t}$ is the occupational licensing regulations (and its components) in person $i$ 's state $s$ in year $t ; \boldsymbol{X}_{i s t}$ is the vector that includes covariates measuring characteristics of each person; $\delta$ and $\theta$ are state and year fixed effects, respectively; and $\varepsilon_{i s t}$ is the error term in our panel data. ${ }^{4}$

The model is a basic fixed effects approach that can also be viewed as

4. The use of a Rasch measure resulted in no basic effect of regulation on either wage determination or hours worked; consequently, we use the summated rating scale. 
a generalization of the conventional two-group, two-period differencein-difference model. ${ }^{5}$ The estimates presented in the tables show the results for both a traditional panel estimate using individuals as the unit of observation of the role of regulation on wage determination and a two-stage estimation procedure. For the two-stage procedure, the first stage is developed by estimating a model of individual-level outcomes on covariates and a full set of state $x(\times)$ time fixed effects. The coefficients on the state $x(\times)$ time fixed effects represent state $x$ time mean outcomes that have been purged of the variation associated with the within-cell variation in the covariates. In the second stage, these adjusted cell-level means are estimates on the policy variables and fixed effects. The two-step approach is a way of performing aggregation while still allowing for adjustment of individual-level covariates, which is a limitation of the pure aggregation. The basic panel estimates include individual covariates as well as state and year fixed effects. ${ }^{6}$

Table 7.6 shows estimates from the model developed from the overall licensing index on wage determination using both the individual observations and the two-level analyses with controls. Since the index is an imprecise measurement of regulation, we develop a relative measure of regulation of high, medium, and low levels of regulation using our index. We then compare the highest levels of regulation relative to the low and medium ones. The first column shows the basic bivariate relationship between having the most restrictive licensing statutes and wage determination with the full sample of the ACS. The basic relationship shows a statistically significant 2 percent effect. ${ }^{7}$ However, in the second column, when human capital and state specific covariates are included, the estimates are still positive but small and not statistically significant. In examining the various engineering specializations in columns (3) through (8), we can see that there is some variation. For example, the bivariate estimates for civil engineers show a positive but small influence of being in a state with the most stringent regulations in the first stage, but no effect in the second stage. Similarly, for both electrical and industrial engineers, the engineering regulations have a small but positive effect in the first-stage bivariate estimates, but no influence in the secondstage results. The significant estimates range from a high of 4 percent with no covariates for industrial engineers with no covariates to no effect in the fully specified model. The categorical specifications show regulation for engineers has a small effect that is close to zero. For engineers, occupational licensing does not appear to influence wage determination for the occupation where

5. We also included time-varying state-level controls, such as the state median household income, but found that they have no explanatory power. Consequently, we do not show the results in this chapter.

6. The standard errors for these models were computed using a Huber-White covariance matrix that allowed for clustering at the state level.

7. We also estimated models that examined the influence of tougher licensing before and after the great recession of 2008, and found results similar to those presented in tables 7.6, 7.7, 7.9, and 7.10. 
Table 7.6

Influence of statutory rank index on wage determination: High relative to medium and low

\begin{tabular}{lcccccccc}
\hline & $\begin{array}{c}(1) \\
\text { One-level } \\
\text { analysis }\end{array}$ & $\begin{array}{c}(2) \\
\text { Two-level } \\
\text { analysis }\end{array}$ & $\begin{array}{c}(3) \\
\text { One-level } \\
\text { analysis }\end{array}$ & $\begin{array}{c}(4) \\
\text { Two-level } \\
\text { analysis }\end{array}$ & $\begin{array}{c}(5) \\
\text { One-level } \\
\text { analysis }\end{array}$ & $\begin{array}{c}(6) \\
\text { Two-level } \\
\text { analysis }\end{array}$ & $\begin{array}{c}(7) \\
\text { One-level } \\
\text { analysis }\end{array}$ & $\begin{array}{c}\text { Two-level } \\
\text { analysis }\end{array}$ \\
\hline Sample & All & All & Civil & Civil & Electrical & Electrical & Industrial & Industrial \\
Highest rank & $0.024^{* * *}$ & 0.007 & $0.013^{* * *}$ & -0.008 & $0.023^{* * *}$ & 0.026 & $0.042^{* * *}$ & -0.014 \\
& $(0.000)$ & $(0.016)$ & $(0.001)$ & $(0.023)$ & $(0.001)$ & $(0.028)$ & $(0.001)$ & $(0.034)$ \\
Observations & $7,231,650$ & 612 & $3,404,866$ & 612 & $2,300,115$ & 605 & $1,526,669$ & 580 \\
$R^{2}$ & 0.000 & 0.852 & 0.000 & 0.715 & 0.000 & 0.706 & 0.000 & 0.580 \\
Basic control & No & Yes & No & Yes & No & Yes & No & Yes \\
Year fixed & No & Yes & No & Yes & No & Yes & No & Yes \\
State fixed & No & Yes & No & Yes & No & Yes & No & Yes \\
\hline
\end{tabular}

Note: Estimated with age, schooling in years, gender, marital status, experience, experience squared, race, U.S. citizenship, for-profit sector, and self-employment. Two-stage regressions are weighted by the number of engineers. The second-stage estimates are aggregate state-level estimates of hours worked calculated from the predicted hours worked in the individual model, which are then aggregated to the state level. The ACS sample uses individuals who earn less than $\$ 250$ per hour and who are college graduates. Standard errors are in parentheses.

***Significant at the 1 percent level.

**Significant at the 5 percent level.

*Significant at the 10 percent level.

there is a relatively modest form of regulation with many unlicensed competitors. This is not unlike some of the specifications of the influence of unions on wage determination for other professional organizations (Lewis 1986). Moreover, we only have estimates of licensing coverage and not those who have attained a license, which may bias our results downward (Gittleman and Kleiner 2016). However, licensing requirements may also have effects on the supply of hours to the market.

The models developed for hours of work use approaches similar to the ones developed for our wage equation models. In a similar manner, we examine employment growth for each of the categories of engineers from 2001 to 2012. The basic model is of the following form:

$$
\ln \left(E_{i s t}\right)=\alpha+\beta R_{s t}+\phi T_{i s t}+\gamma X_{i s t}+\delta_{s}+\theta_{t}+\varepsilon_{i s t},
$$

where Employment ${ }_{i s t}$ is hours of work per week per engineer in state $s$ in time period $t$ for individual $i ; T_{i s t}$ is the type of engineer at state $s$ in time period $t$ for individual $i ; R_{s t}$ is the regulation measure and its components at state $s$ in time period $t$; the vector $\boldsymbol{X}_{s t}$ includes covariates measuring economic and human capital characteristics within each state; $\delta_{s}$ and $\theta_{t}$ are state and year fixed effects, respectively; and $€_{i s t}$ is the error term.

Table 7.7 gives the basic results for the effect of the licensing index on hours of work supplied by engineers using the specified model with regulations measured as in the high category relative to low or medium categorical measures of regulation. The results are consistent in showing that regulation is associated with an increase in hours worked by about 1 percent in the 
Influence of statutory rank index on hours worked: High relative to medium and low

\begin{tabular}{|c|c|c|c|c|c|c|c|c|}
\hline & $\begin{array}{c}(1) \\
\text { One-level } \\
\text { analysis }\end{array}$ & $\begin{array}{c}(2) \\
\text { Two-level } \\
\text { analysis }\end{array}$ & $\begin{array}{c}(3) \\
\text { One-level } \\
\text { analysis }\end{array}$ & $\begin{array}{c}\text { (4) } \\
\text { Two-level } \\
\text { analysis }\end{array}$ & $\begin{array}{c}(5) \\
\text { One-level } \\
\text { analysis }\end{array}$ & $\begin{array}{c}(6) \\
\text { Two-level } \\
\text { analysis }\end{array}$ & $\begin{array}{c}(7) \\
\text { One-level } \\
\text { analysis }\end{array}$ & $\begin{array}{c}(8) \\
\text { Two-level } \\
\text { analysis }\end{array}$ \\
\hline $\begin{array}{l}\text { Sample } \\
\text { Highest rank }\end{array}$ & $\begin{array}{c}\text { All } \\
0.010^{* * *} \\
(0.000)\end{array}$ & $\begin{array}{c}\text { All } \\
0.009 \\
(0.006)\end{array}$ & $\begin{array}{l}\text { Civil } \\
0.010^{* * *} \\
(0.000)\end{array}$ & $\begin{array}{c}\text { Civil } \\
0.010 \\
(0.008)\end{array}$ & $\begin{array}{c}\text { Electrical } \\
0.015^{* * *} \\
(0.000)\end{array}$ & $\begin{array}{c}\text { Electrical } \\
0.012 \\
(0.009)\end{array}$ & $\begin{array}{c}\text { Industrial } \\
0.005^{* * *} \\
(0.000)\end{array}$ & $\begin{array}{c}\text { Industrial } \\
0.008 \\
(0.011)\end{array}$ \\
\hline Observations & $7,231,650$ & 612 & $3,404,866$ & 612 & $2,300,115$ & 605 & $1,526,669$ & 580 \\
\hline$R^{2}$ & 0.001 & 0.335 & 0.001 & 0.202 & 0.002 & 0.216 & 0.000 & 0.196 \\
\hline Basic control & No & Yes & No & Yes & No & Yes & No & Yes \\
\hline Year fixed & No & Yes & No & Yes & No & Yes & No & Yes \\
\hline State fixed & No & Yes & No & Yes & No & Yes & No & Yes \\
\hline
\end{tabular}

Note: Estimated with age, schooling in years, gender, marital status, experience, experience squared, race, U.S. citizenship, for-profit sector, and self-employment. Two-stage regressions are weighted by the number of engineers. The second-stage estimates are aggregate state-level estimates of hours worked calculated from the predicted hours worked in the individual model, which are then aggregated to the state level. The ACS sample uses individuals who earn less than $\$ 250$ per hour and who are college graduates. Standard errors are in parentheses.

***Significant at the 1 percent level.

**Significant at the 5 percent level.

*Significant at the 10 percent level.

bivariate estimates, but no effect when the two-level analyses is implemented with standard human capital controls. If regulation is effective in restricting the supply of new entrants to some extent, then those in the occupation are likely to work more hours. The results in table 7.7 are consistent with this hypothesis, but the magnitudes are small and significant in the one-stage estimates and insignificant in the two-stage results.

Although the categorical transformation of the overall index does not show much effect on the key labor market variables of wages and hours worked, perhaps several of the individual components of the licensing index may influence wages and hours worked. The use of an examination to determine the effect of this variable on wage determination has been used in other studies (Kleiner and Kudrle 2000; Kleiner and Krueger 2013). Through the examination process and the establishment of higher standards, access to and supply of engineers can be reduced, and if demand remains constant, wages can increase. Moreover, the pass rate for the engineering exam also may limit the entry of new engineers and drive up wages for engineers.

In table 7.8 we list the states that require a professional exam for each specific type of licensing examination. In order to become licensed, engineers usually take a fundamental or first exam, the basic step toward becoming a licensed engineer. This exam is often administered to engineers just prior to their finishing undergraduate studies. The professional exam, in contrast, covers general engineering practices and is usually given after engineers have been practicing for four or more years. It is the final stage of licensing coverage for entry into the regulated part of the occupation. Table 7.8 shows that Ohio and Arkansas adopted a professional exam in 2002 and 2009, 
Table 7.8 State professional exam requirements for licensure of engineers, 2001-2012

\begin{tabular}{llc}
\hline Professional exam required & No professional exam required & Changer (year of change) \\
\hline Alabama & Hawaii & Ohio (2002) \\
Alaska & Missouri & \\
Arizona & New Hampshire & \\
California & New Jersey & \\
Colorado & New Mexico \\
Connecticut & Oregon & \\
Delaware & South Dakota & \\
District of Columbia & Utah & \\
Florida & Virginia \\
Georgia & Washington \\
Idaho & Wisconsin & \\
Illinois & Wyoming \\
Indiana & \\
Iowa & \\
Kansas & \\
Kentucky & \\
Louisiana & \\
Maine & \\
Maryland & \\
Massachusetts & \\
Michigan & \\
Minnesota & \\
Mississippi & \\
Montana & \\
Nebraska & \\
Nevada & \\
New York & \\
North Carolina & \\
North Dakota & \\
Oklahoma & \\
Pennsylvania & \\
Rhode Island & \\
South Carolina & \\
Tennessee & \\
Texas & \\
Vermont & \\
West Virginia & \\
\hline
\end{tabular}

respectively; they serve as the basis for a difference-in-difference analysis. The difference-in-difference model is relative to Ohio and Arkansas, which were the states that changed their regulatory statutes for exams over the time period for which we have data and part of our analysis.

In order to provide sensitivity analysis for our previous estimates and include the estimates for an additional regulatory requirement, we include whether there is a professional exam requirement to become licensed. 
Table 7.9 shows the estimates on wage and hours using seemingly unrelated regression (SUR) methods for the influence of having a professional exam requirement as part of the licensing requirement. Since only two states changed the exam requirements during the period under study, we used this method as an additional sensitivity test of our estimates. Panel A shows the results when engineers are categorized by type of engineering field: civil, electrical, and industrial. In panel B we estimate the model for all the engineers in our sample. Those estimates are consistent with the general results shown in tables 7.6, 7.7, and 7.8 and show only a small coefficient size for this requirement and varying levels of significance based on the type of engineering specialty and the labor market outcome variable selected, which was hourly wages or hours worked.

In table 7.10, we examine whether the lagged professional exam requirement variable may have influenced economic factors. Using the lagged professional licensing requirement and current economic data starting in 2001 through 2012, the table shows that these results are consistent in displaying a mixed to minor influence on wage determination. At least for licensing coverage, which is what our data allow us to measure, occupational licensing has a small influence on wage determination for civil engineers, but has a mixed influence on other engineering specialties. This may reflect the fact that the attainment of a license matters more with respect to wage determination, rather than the passage of a law regulating an occupation that is largely unregulated by the government (Gittleman and Kleiner 2016). Even though $\mathrm{H}$. Gregg Lewis finds that being represented by a union raises wages by about 15 percent in aggregate, for many occupations such as hospital workers and well-educated male workers, the influence of unions is either zero or even slightly negative (Lewis 1986). Similarly, for civil engineers, who are more heavily licensed, tougher regulations may not enhance their earnings, perhaps because unregulated workers are able to be more innovative and create new markets relative to engineers who have their work standardized by the government (Friedman 1962).

\subsection{Conclusions}

Our chapter presents the first comprehensive analysis of the role of occupational licensing requirements on the labor market for civil, electrical, and industrial engineers. These groups of engineers represent among the largest number of engineers that are covered by occupational licensing statutes in the United States. We initially trace the historical evolution of licensing for engineers. Second, we present a theoretical rationale for the role of government in the labor market for the occupation. In the model, the government's ability to control supply through licensing restrictions and the pass rate limits the number of engineers, which may drive up wages. These results are useful for informing the empirical models for engineers. 


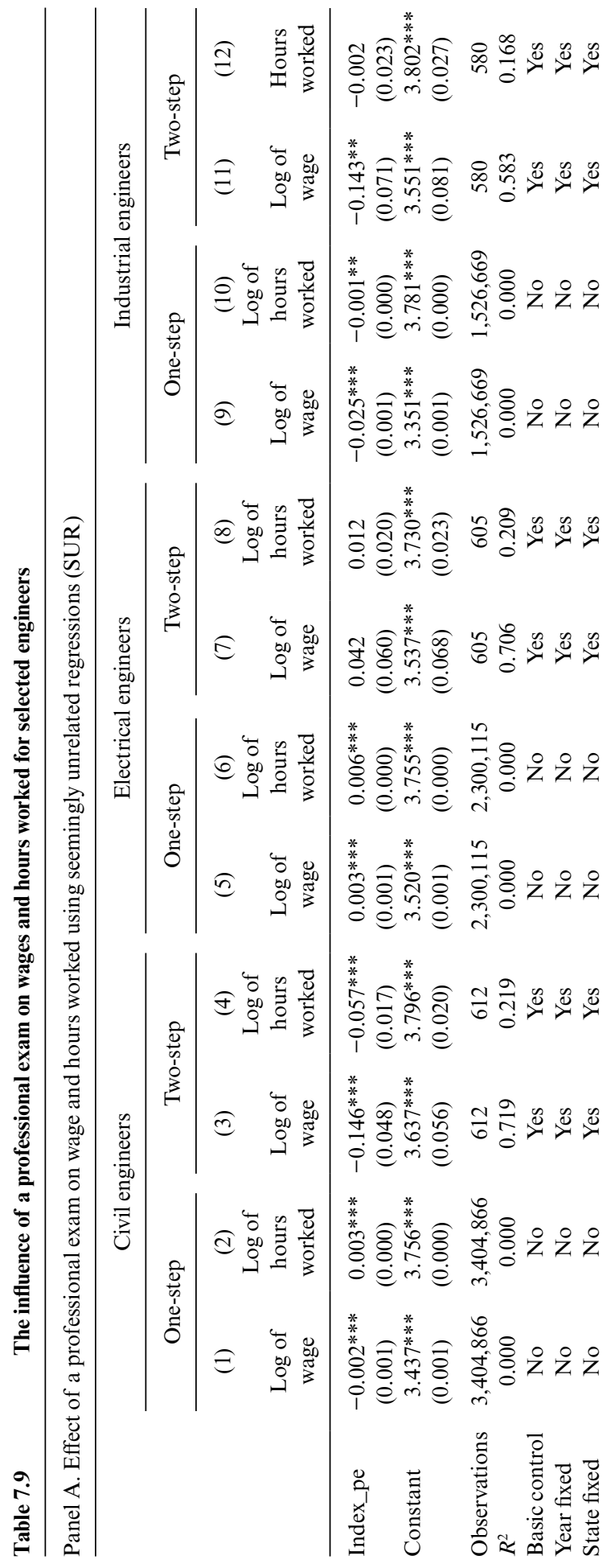




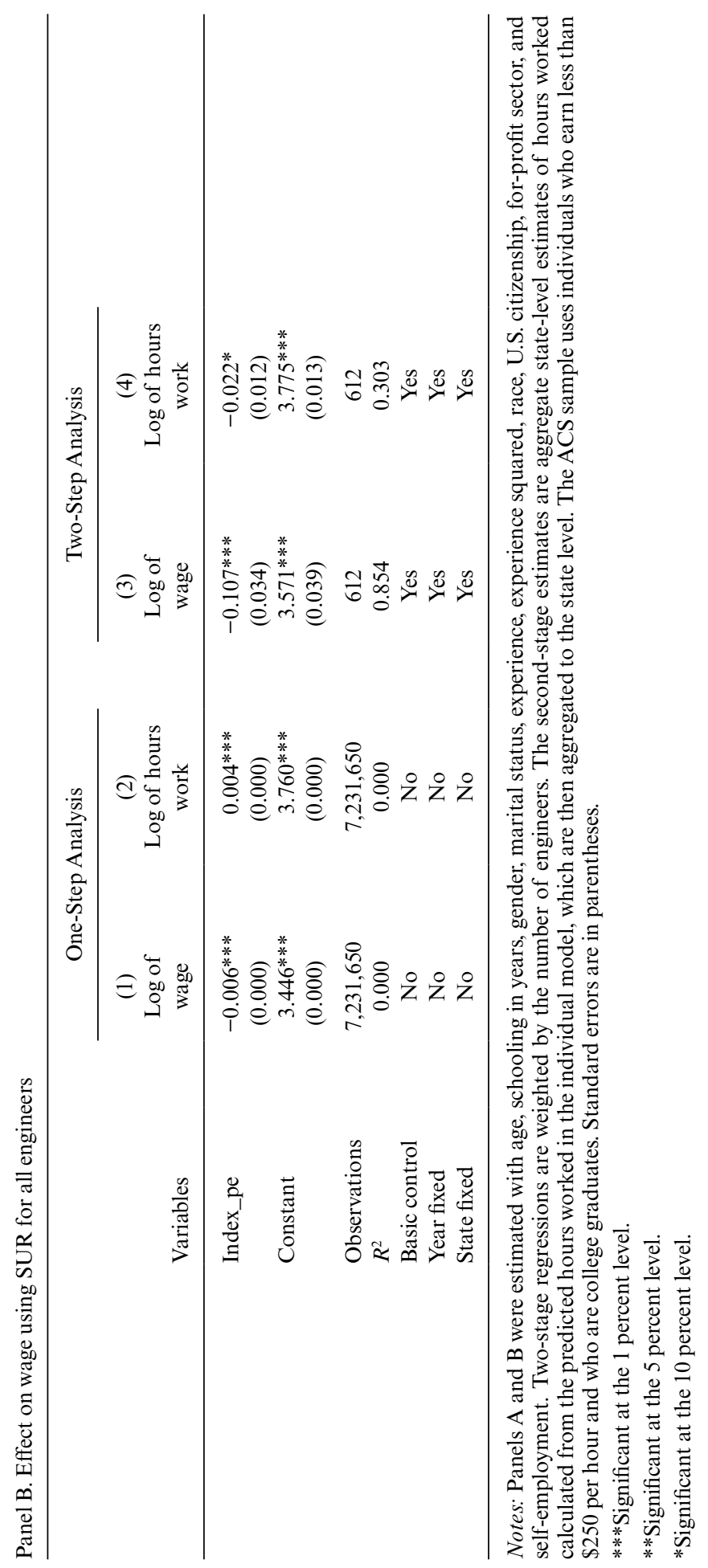

You are reading copyrighted material published by University of Chicago Press. 


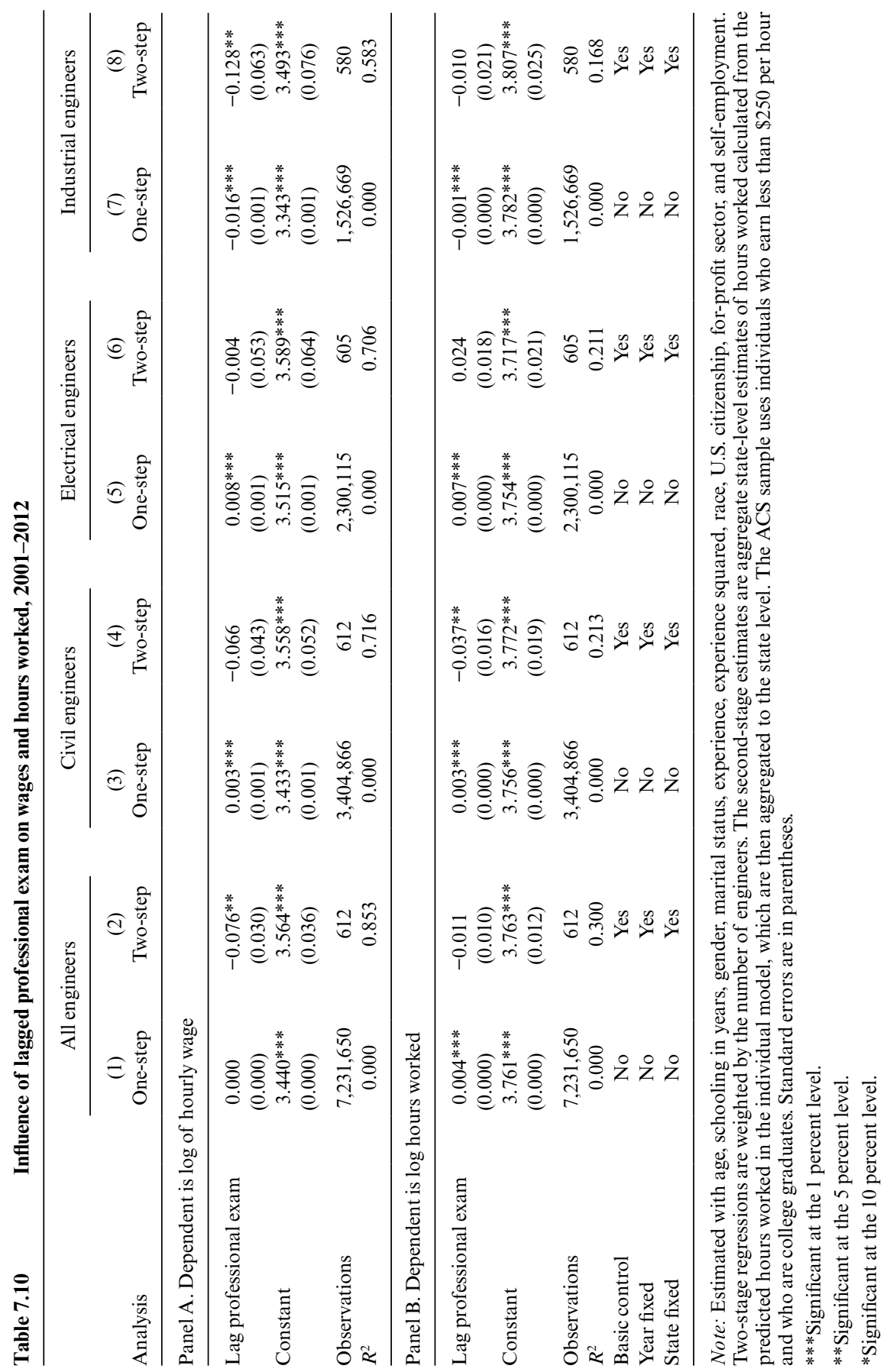


In the empirical section, we show that licensing for these occupations has grown somewhat more rigorous during the period 2001-2012. We then estimate a panel-data model for the engineers in our sample using the ACS. Our estimates show a small influence of occupational licensing on both wages and employment in a variety of specifications and sensitivity analysis tests. In the U.S. economy, if engineers achieve the goal of their professional association of more rigid requirements, and a longer time to become an engineer, the growth of regulation of the occupation may reduce customer access to engineers and slow down the ability of builders and manufacturers to use regulated engineering services. Our study provides a first look at these issues. Exploring the potential issue of selection across engineering specialties, and using more detailed analysis such as the use of discontinuities when the passage of more rigorous laws occurs, may provide more refined or precise estimates and examples of the role of regulation in the market for engineers. Further, a more thorough analysis would include individuals who have attained a license rather than licensing coverage, and these data would allow us to obtain a better measure of the influence of occupational licensing on those who chose to get the credential to legally do certain engineering tasks. Nevertheless, engineers may be seeking greater control over the supply of engineers, but have not attained the level of labor market control that other occupations such as dentists or electricians have been able to gather over time. When the licensing of engineers influences not only the broad coverage of the law in the field, but also the occupational attainment of workers in the profession, they can obtain what many other licensed professionals have been able to acquire in the labor market. 


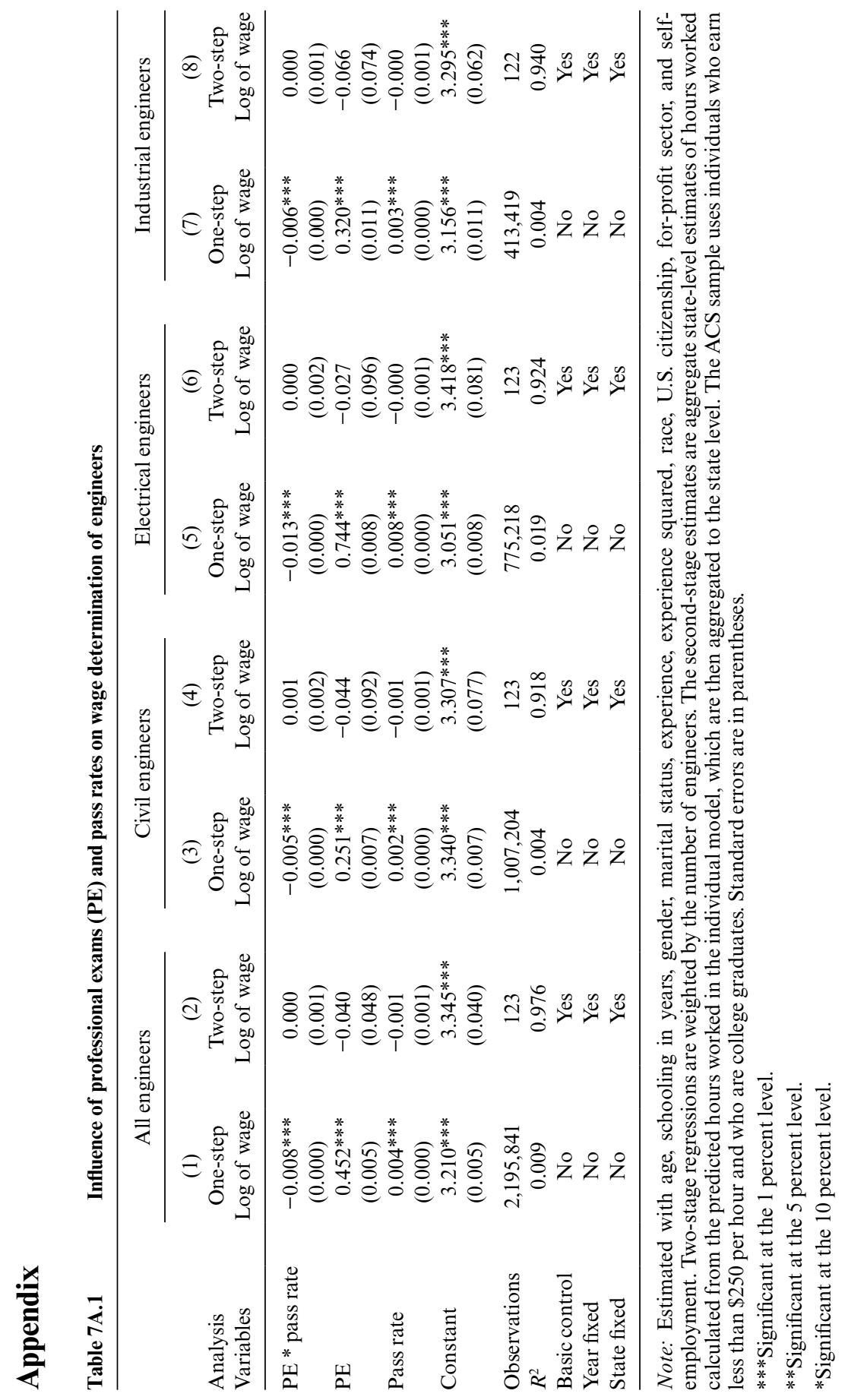




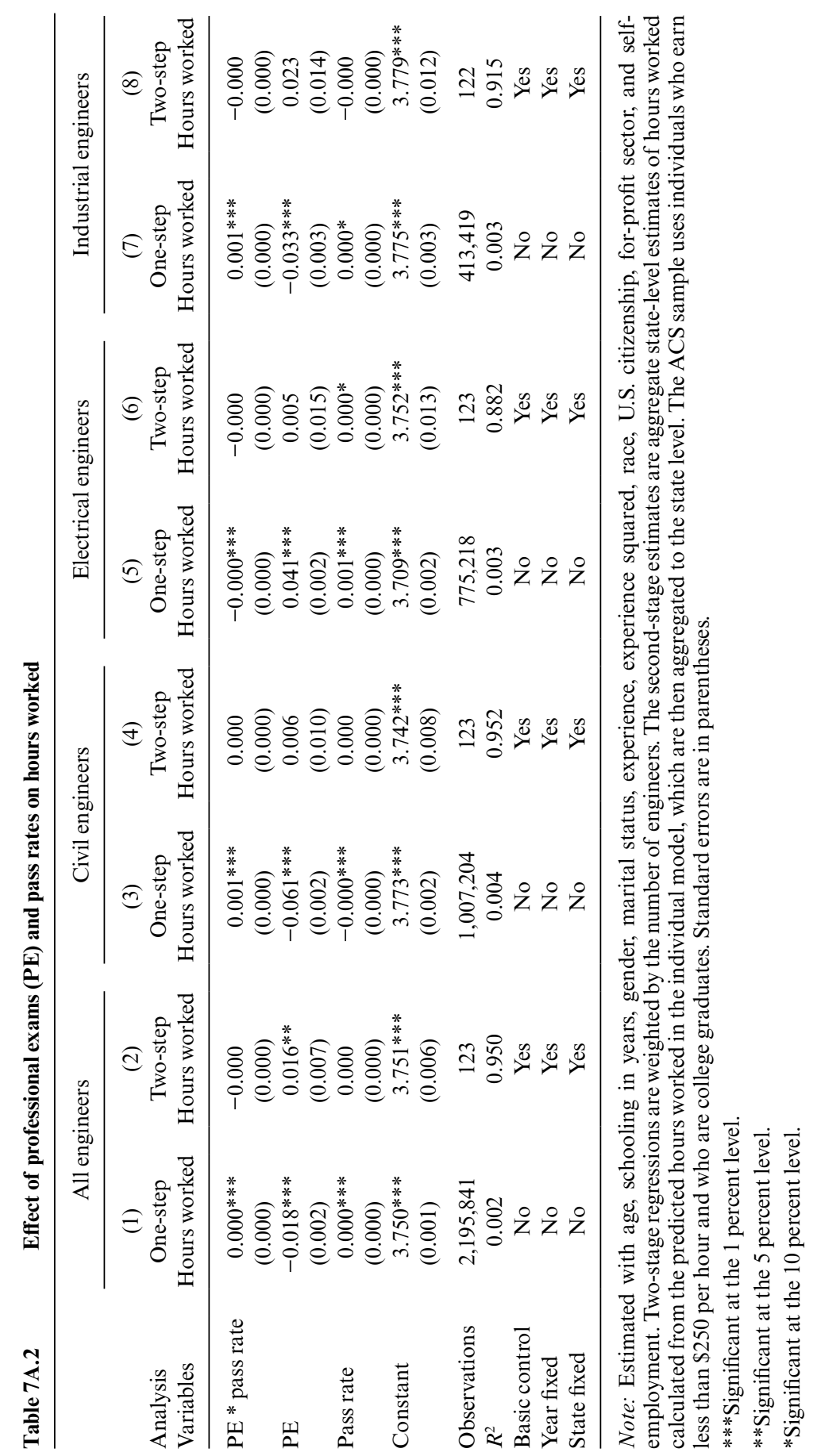




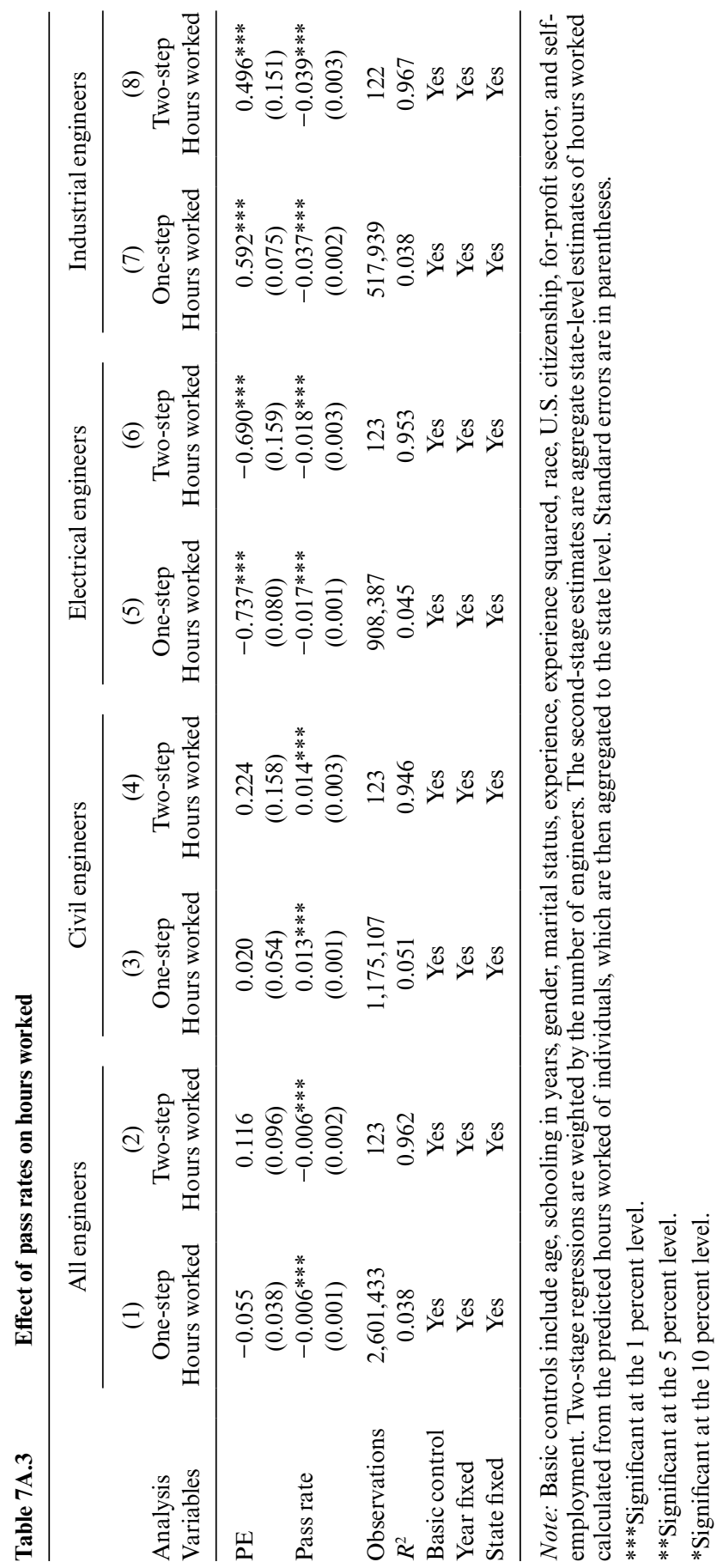




\section{References}

Brinegar, P., and K. Schmitt. 1992. "State Occupational and Professional Licensure." In The Book of the States, 1992-1993, 567-80. Lexington, KY: Council of State Governments.

Council of State Governments. 1952. Occupational Licensing Legislation in the States. Chicago: Council of State Governments.

Dunlop, J. T. 1958. Industrial Relations Systems. New York: Holt.

Folk, H. 1970. The Shortage of Scientists and Engineers. Lexington, MA: Lexington Press.

Freeman, R. B. 1976. "A Cobweb Model of the Supply and Starting Salary of New Engineers." Industrial and Labor Relations Review 29 (2): 236-48.

Friedman, Milton. 1962. Capitalism and Freedom. Chicago: University of Chicago Press.

Gittleman, M., and M. M. Kleiner. 2016. "Wage Effects of Unionization and Occupational Licensing Coverage in the United States." Industrial and Labor Relations Review 69 (1): 142-72.

Haber, S. 1991. The Quest for Authority and Honor in the American Professions, 17501900. Chicago: University of Chicago Press.

Hansen, W. L. 1961. "The Shortage of Engineers.” Review of Economics and Statistics 43 (3): 251-56.

Hirsch, B. T., and D. A. Macpherson. 2011. "Union Membership and Coverage Database from the Current Population Survey." September. http://www.unionstats .com.

Kleiner, M. M. 2006. Licensing Occupations: Ensuring Quality or Restricting Competition? Kalamazoo, MI: W. E. Upjohn Institute.

. 2013. Stages of Occupational Regulation: Analysis of Case Studies. Kalamazoo, MI: W. E. Upjohn Institute.

Kleiner, M. M., and A. B. Krueger. 2010. "The Prevalence and Effects of Occupational Licensing." British Journal of Industrial Relations 48 (4): 676-87.

. 2013. "Analyzing the Extent and Influence of Occupational Licensing on the Labor Market." Journal of Labor Economics 31 (2): S173-202.

Kleiner, M., and R. Kudrle. 2000. "Does Regulation Affect Economic Outcomes? The Case of Dentistry." Journal of Law and Economics 43 (2): 547-82.

Kleiner, M., and R. Todd. 2009. "Mortgage Broker Regulations That Matter: Analyzing Earnings, Employment, and Outcomes for Consumers." In Studies of Labor Market Intermediation, edited by D. Autor. Chicago: University of Chicago Press.

Lewis, H. Gregg. 1986. Union Relative Wage Effects: A Survey. Chicago: University of Chicago Press.

Perloff, J. M. 1980. "The Impact of Licensing Laws on Wage Changes in the Construction Industry." Journal of Law and Economics 23 (2): 409-28.

Pfatteicher, S. K. A. 1996. "Death by Design: Ethics, Responsibility and Failure in the American Civil Engineering Community, 1852-1986." PhD diss., University of Wisconsin-Madison.

Princeton Data Improvement Initiative (PDII). 2008. http://www.krueger.princeton .edu/PDIIMAIN2.htm.

Rubin, D. K., and J. L. Tuchman. 2012. "Professional Engineers' License Debate Grows in Intensity." Engineering News-Record Oct. 17, pp. 1-2.

Russell, J., and W. B. Stouffer. 2003. "Change Takes Time: The History of Licensure and Continuing Professional Competency." Report, American Society of Civil Engineers http://www.enr.com/articles/2911-professional-engineers-licensedebate-grows-in-intensity? $\mathrm{v}=$ preview.

U.S. Department of Labor, Bureau of Labor Statistics. 2013. Current Population Survey. 